\title{
Author Correction: Enhancement of trans-cleavage activity of Cas12a with engineered crRNA enables amplified nucleic acid detection
}

\author{
Long T. Nguyen, Brianna M. Smith \& Piyush K. Jain
}

Correction to: Nature Communications https:/doi.org/10.1038/s41467-020-18615-1, published online 30 September 2020.

In the original version of this Article, the composition of buffer D in the "Methods" section "LbCas12a expression and purification" was incorrectly provided as "( $100 \mathrm{mM} \mathrm{NaCl}, 20 \mathrm{mM}$ HEPES, $0.5 \mathrm{mM}$ TCEP, $\mathrm{pH}=8)$ ". It should have read "(2 M NaCl, $20 \mathrm{mM}$ HEPES, $0.5 \mathrm{mM}$ TCEP, $\mathrm{pH}=8)$ ”.

This has been corrected in both the PDF and HTML versions of this Article.

Published online: 24 November 2020

(c) Open Access This article is licensed under a Creative Commons Attribution 4.0 International License, which permits use, sharing, adaptation, distribution and reproduction in any medium or format, as long as you give appropriate credit to the original author(s) and the source, provide a link to the Creative Commons license, and indicate if changes were made. The images or other third party material in this article are included in the article's Creative Commons license, unless indicated otherwise in a credit line to the material. If material is not included in the article's Creative Commons license and your intended use is not permitted by statutory regulation or exceeds the permitted use, you will need to obtain permission directly from the copyright holder. To view a copy of this license, visit http://creativecommons.org/licenses/by/4.0/.

This is a U.S. government work and not under copyright protection in the U.S.; foreign copyright protection may apply 2020 